\title{
PERANCANGAN MOTIF KHAS TASIKMALAYA PADA DECOUPAGE UNTUK PRODUK DARI ANYAMAN PANDAN
}

\author{
Imamul Masyhudi ${ }^{1}$ \\ Kresnawan Budiargo ${ }^{2}$
}

\author{
Diterima Oktober. 29, 2021; Disetujui Desember. 15, 2021
}

\begin{abstract}
Abstrak: Anyaman Tasikmalaya mampu menembus pasar ekspor di tiga negara, yaitu Jepang, Italia, dan Spanyol. Di tengah pesatnya perkembangan produk ini, terselip permasalahan, yaitu perkembangan motif gambar yang kurang variatif. Teknik gambar decoupage lebih diminati konsumen dari pada teknik gambar tangan manual. Perancangan motif decoupage ini menggunakan metodologi tiga tahapan, yaitu eksplorasi, perancangan dan perwujudan. Dalam perancangan didapatkan bahwa banyak motif khas yang bisa digali dari Tasikmalaya, misalkan motif flora, fauna, alam dan budaya. Tujuan perancangan ini adalah memberikan motif khas pada produk anyaman sehingga memiliki keunikan serta identitas Tasikmalaya.
\end{abstract}

Kata kunci : anyaman; decoupage; motif khas; produk ekspor

\begin{abstract}
Tasikmalaya woven is able to penetrate the export market in three countries; Japan, Italy and Spain. In the midst of the rapid development of this product, there are problems, the development of image motifs that are less varied. The decoupage drawing technique is more attractive to consumers than the manual hand drawing technique. The design of this decoupage motif uses a three-step methodology; exploration, design and embodiment. In the design, it was found that many distinctive motifs could be extracted from Tasikmalaya, for example flora, fauna, nature and culture motifs. The purpose of this design is to give a distinctive motif to the woven product so that it has the uniqueness and identity of Tasikmalaya.
\end{abstract}

Keywords: woven; decoupage; distinctive motifs; export product

\footnotetext{
${ }^{1}$ Imamul Masyhudi adalah staf pengajar pada Fakultas Seni dan Desain Universitas Multimedia Nusantara (UMN) Tangerang.
}

${ }^{2}$ Kresnawan Budiargo adalah staf pengajar pada Tempo Polytechnic. e-mail : imamul.masyhudi@lecturer.umn.ac.id

e-mail:argo.phob@gmail.com 


\section{Pendahuluan}

Sang Mutiara dari Priangan Timur adalah julukan bagi Tasikmalaya. Banyak kerajinan yang berasal dari kota ini, misalnya payung dan kelom geulis, serta kerajinan anyaman di daerah Rajapolah, tepatnya di kampung kreatif Sukaruas.

Banyak ragam dan jenis dari anyaman ini, mulai yang berbahan pandan, panama, hingga dari batang eceng gondok. Bentuknya yang dulu hanya berupa tikar, saat ini telah berkembang. Dari dompet berukuran kecil, hingga beragam tas dan topi dengan berbagai model. Meski sekilas terlihat sederhana, namun produk ini telah mampu menembus pasar ekspor di tiga negara, yaitu Jepang, Italia, dan Spanyol.

Bahan yang alami mampu menarik minat banyak pembeli, khususnya dari luar negeri. Pasar ini mampu ditangkap sehingga menjadi peluang yang menguntungkan. Saat order banyak, seringkali para pengrajin tidak mampu memenuhi permintaan. Selain karena kurangnya bahan dan terbatasnya SDM, hal ini juga dikarenakan proses produksinya masih tradisional dengan alat yang sederhana.

Di tengah pesatnya perkembangan produk anyaman ini, terselip permasalahan. Permasalahan ini dapat dibagi menjadi dua; pertama, permasalahan yang bersifat umum yaitu minimnya dukungan pemerintah, semakin turunnya minat generasi muda untuk meneruskan bisnis di bidang kerajinan ini, kesadaran masyarakat terhadap kualitas produk yang masih rendah, hingga permodalan yang sulit untuk mendapat pinjaman dari lembaga keuangan formal/perbankan.

Kedua, permasalahan khusus yang dialami pengrajin anyaman, yaitu perkembangan motif dan gambar. Dulu anyaman dihias dengan motif sederhana yang bisa digambar dengan tangan. Teknik ini memakan waktu yang lama juga kurang diminati oleh konsumen. Seiring perkem- bangan zaman muncul banyak teknik lainnya, salah satunya adalah teknik decoupage. Decoupage adalah seni menghias sebuah benda dengan cara menempel potongan-potongan kertas berwarna pada permukaannya. Seni menempel ini berkembang menjadi lebih praktis dengan banyak kertas motif yang sudah siap ditempel tanpa harus dipotong-potong lagi. Motif di kertas ini memiliki banyak ragam, baik itu flora, fauna maupun motif lainnya. Sayangnya tidak terdapat motif khas Tasikmalaya. Padahal teknik tempel gambar ini ternyata sangat menarik minat para konsumen.

Perancangan ini dikhususkan pada permasalahan kedua yaitu belum adanya motif khas pada decoupage untuk produk anyaman yang mencirikan Tasikmalaya. Permasalahan ini penting karena motif yang khas akan menciptakan produk yang unik serta bisa menjadi unggulan. Menurut Kotler (2003), diferensiasi didefinisikan sebagai tindakan untuk menetapkan sekumpulan perbedaan-perbedaan yang mempunyai nilai guna untuk membedakan penawaran perusahaan dari pesaingnya. Dalam perancangan ini diferensiasi diciptakan dengan menggali ciri khas Tasikmalaya.

Dengan demikian produk anayaman dengan motif pada decoupage ini tidak lagi sekedar menjadi komoditas semata melainkan juga menjadi salah satu kekayaan budaya.

\section{Metodologi Penelitian}

Dalam proses penciptaan motif decoupage untuk anyaman perancang menggunakan metode tiga tahap enam langkah. Menurut Gustami SP proses penciptaan sebuah karya seni dapat dilakukan secara intuitif, tetapi dapat pula ditempuh melalui metode ilmiah yang direncanakan secara seksama, analitis, dan sistematis. Dalam konteks metod- 
ologis, terdapat tiga tahap enam langkah dalam penciptaan sebuah karya seni, yaitu eksplorasi, perancangan dan perwujudan.

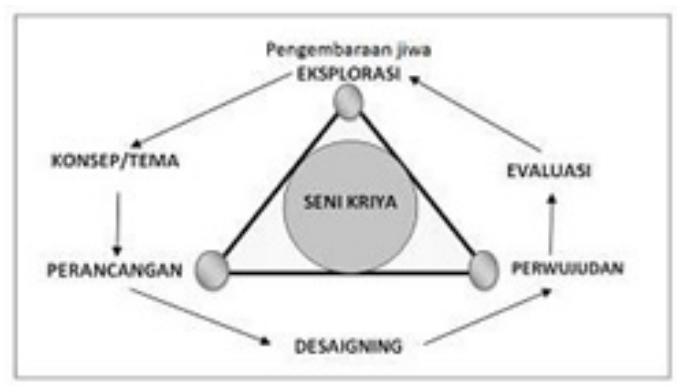

Gambar 1. Tiga tahap-enam langkah proses penciptaan karya seni kriya.

(Sumber: Gustami Sp 125: 2007)

Perancangan ini dimulai dengan eksplorasi kemudian dilanjutkan dengan proses perancangan hingga ke perwujudan karya. Dilakukan juga uji estetika dan ciri khas terhadap desain motif decoupage untuk anyaman yang dihasilkan.

Eksplorasi meliputi langkah pengembaraan jiwa, dan penjelajahan dalam menggali sumber ide. Dari kegiatan ini akan ditemukan tema dan berbagai persoalan. Pada tahap ini juga dilakukan observasi dan interview.

\section{Observasi}

Observasi dilakukan pada para pengrajin di Tasikmalaya untuk mengetahui proses pembuatan anyaman.

\section{Interview}

Teknik pengumpulan data ini dilakukan dengan cara bertatap muka langsung dengan narasumber utama pengrajin anyaman Bapak Dadang, serta sumber lainnya, sumber lain ini diantaranya pembeli/ konsumen/ target market produk anyaman ini.

Setelah mendapatkan cukup data, masuk ke tahap berikutnya yaitu Perancangan, yang terdiri dari kegiatan menuangkan ide dari hasil analisis yang telah dilakukan ke dalam bentuk dua dimensional. Hasil perancangan tersebut selanjutnya diwujudkan dalam bentuk karya.

Semua tahapan dan langkah yang telah dilakukan perlu dilakukan evaluasi untuk mengetahui secara menyeluruh terhadap kesesuaian antara gagasan dengan karya yang diciptakan (Gustami, 2007).

Hal menarik yang didapat saat interview, khususnya pada produk anyaman tas adalah bahwa yang paling penting dan menjadi penentu pembelian, urutannya adalah sebagai berikut:

1. Bentuk tas anyaman

2. Harga

3. Motif atau gambar yang ada di tas

4. Warna

Berikut beberapa contoh tas anyaman Tasikmalaya yang motifnya masih digambar dengan tangan secara manual:

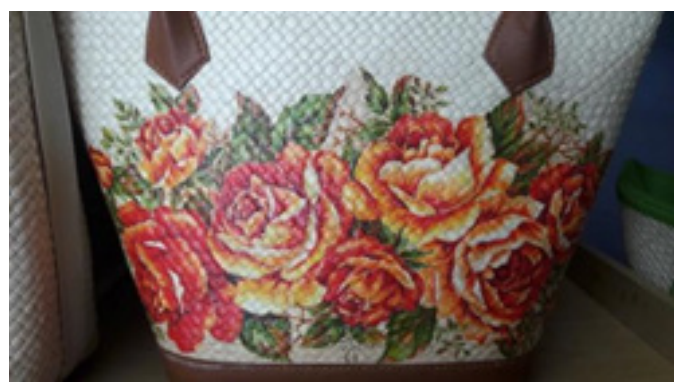

Gambar 2. Tas anyaman motif bunga (Sumber: Masyhudi, 2017)

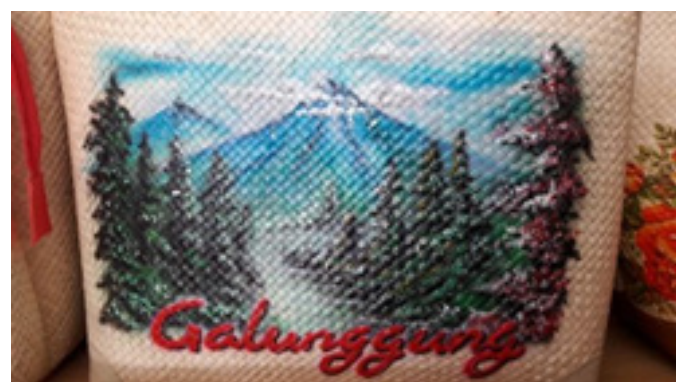

Gambar 3. Tas anyaman motif pemandangan (Sumber: Masyhudi, 2017) 


\section{Imamul Masyhudi ${ }^{1}$ Kresnawan Budiargo ${ }^{2}$}

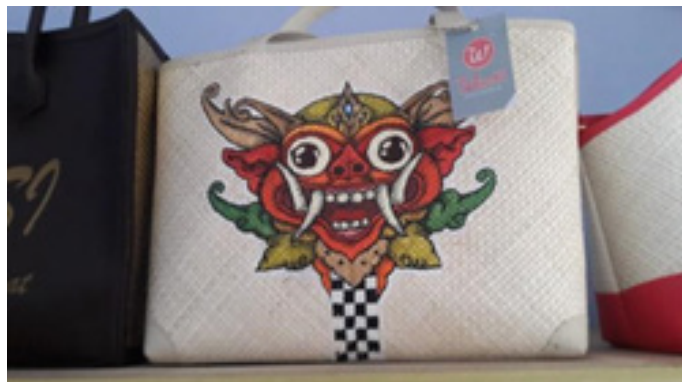

Gambar 4. Tas anyaman motif budaya (Sumber: Masyhudi, 2017)

Dari interview ini, didapatkan juga walau motif bukan pertimbangan utama dari pembeli tapi keberadaanya masih sangat menarik perhatian mereka, terbukti bahwa motif sebagai salah satu elemen desain mampu mengalahkan warna, yang biasanya dominan sebagai salah satu acuan untuk memilih sebuah produk desain.

Urutan motif yang menarik menurut para pembeli/target market adalah:

1. Flora

2. Fauna

3. Pemandangan alam

4. Lainnya (motif geometris, dekoratif)

Produk anyaman yang dihias dengan motif pada decoupage ini kebanyakan berupa tas wanita, dari hal tersebut maka dapat diketahui bahwa target market/ konsumen produk ini adalah wanita, dengan rentang usia 20-50 tahun, dari berbagai kalangan.

Untuk geografis, target bisa dibagi menjadi dua, yaitu:

1. Domestik merupakan target utama. Karakteristik yang paling menonjol dari target market ini adalah lebih menyukai produk dengan gambar yang mencolok, besar dan menarik,

2. Manca negara, khususnya yang telah lama menjadi pelanggan produk
Perancangan Motif Khas Tasikmalaya

pada Decoupage untuk Produk dari

Anyaman Pandan

dari Rajapolah, yaitu Jepang, Italia, dan Spanyol. Karakteristiknya menyukai motif minimalis atau tanpa motif sama sekali, berkesan natural dan go green.

\section{Hasil dan Pembahasan}

Menciptakan motif baru pada decoupage untuk anyaman yang khas Tasikmalaya dengan menonjolkan visual dari keunikan lokal dan berasal dari semua potensi yang ada, Motif baru ini akan diwujudkan dengan gaya desain modern, dinamis, dan kreatif sebagaimana identitas yang telah melekat pada Tasikmalaya.

Gaya desain ditunjukkan lewat penggunaan gambar vektor. Ciri gaya gambar ini adalah flat, tajam, berwarna solid, dan bergradasi kuat. Gaya desain ini sering diaplikasikan ke berbagai media seperti banner, poster, brosur, dan lainnya (ilmunesia.com, 2017).

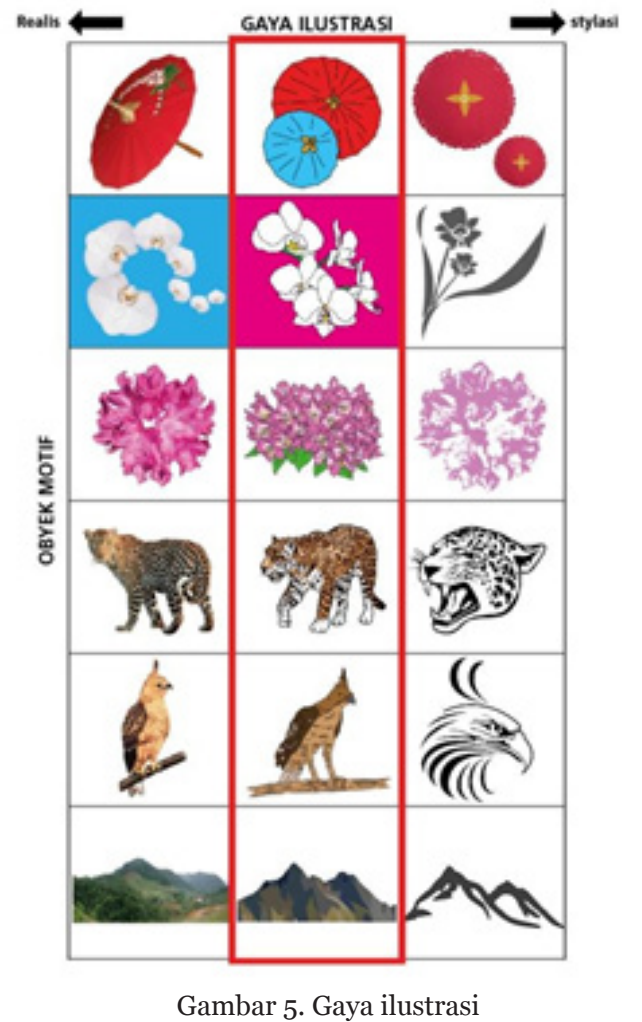

(Sumber: Kresnawan, Masyhudi, 2018) 


\section{Visualisasi Motif Karya}

\section{Motif Tema Potensi Benda Budaya}

Payung Geulis merupakan salah satu benda budaya yang tertua di Tasikmalaya sekaligus benda khas yang menjadi Identitas. Pembuatan Payung Geulis konon dimulai sejak datangnya perantau dari China, yaitu pada masa Dinasti Ch'ing tahun 1644, di mana perdagangan Tiongkok dengan Asia Tenggara kembali dibuka. (Merdeka.com, 2014). Payung Geulis digunakan sebagai gambar utama di lambang Tasikmalaya.

Bentuknya yang unik akan sangat indah jika digunakan sebagai motif baru pengganti motif yang telah ada di pasaran.

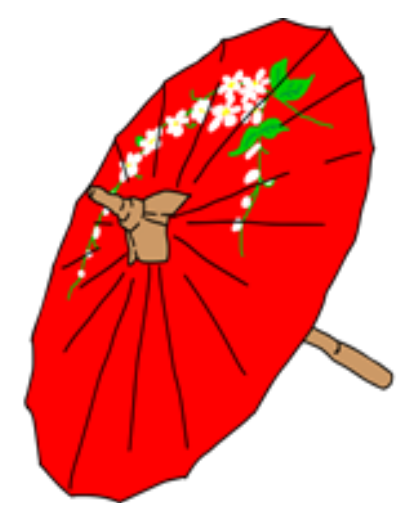

Gambar 6. Payung Geulis

(Sumber: Kresnawan, 2018)

\section{Motif Tema Potensi Flora}

Sulit menemukan flora yang endemik di Tasikmalaya. Selain karena letak geografis yang berada di antara Jawa Barat dan Jawa Tengah, kondisi alam pun tidak berbeda dengan wilayah sekitarnya. Oleh karena itu motif flora diperluas cakupannya ke wilayah Jawa Barat.

Di wilayah ini, didapatkan dua spesies flora yang khas yaitu bunga Anggrek Bulan dan bunga Rhododendron. Dua bunga ini juga memiliki bentuk yang unik sehingga bisa digunakan sebagai gambar ornamen motif anyaman.

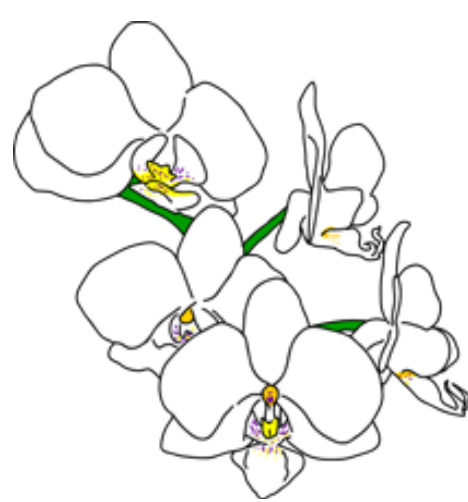

Gambar 7. Bunga Anggrek (Sumber: Kresnawan, 2018)

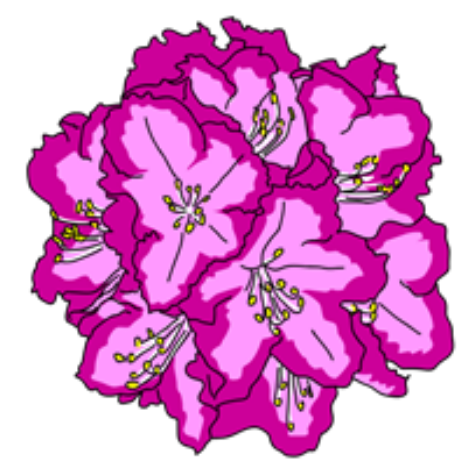

Gambar 8. Bunga Rhododendron (Sumber: Kresnawan, 2018)

\section{Motif Tema Potensi Fauna}

Jawa Barat memiliki fauna endemik yang tidak dimiliki oleh daerah lain. Fauna pertama yang dianggap mewakili Jawa Barat adalah Macan Tutul atau Macan Kumbang.

Warna oranye dengan bintik hitam pada Macan Tutul secara natural sudah indah dipandang mata sehingga sangat cocok digunakan sebagai motif khas anyaman Tasikmalaya.

Selain Macan Tutul, Elang Jawa juga bisa menjadi alternatif yang sangat menarik sebagai motif anyaman. Burung khas Jawa Barat yang berwarna coklat keemasan ini akan sangat elegan jika diaplikasikan pada motif anyaman. 


\section{Imamul Masyhudi ${ }^{1}$ Kresnawan Budiargo ${ }^{2}$}

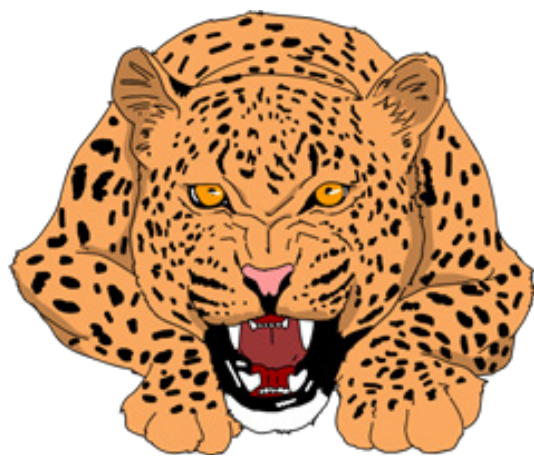

Gambar 9. Macan Tutul (Sumber: Kresnawan, 2018)

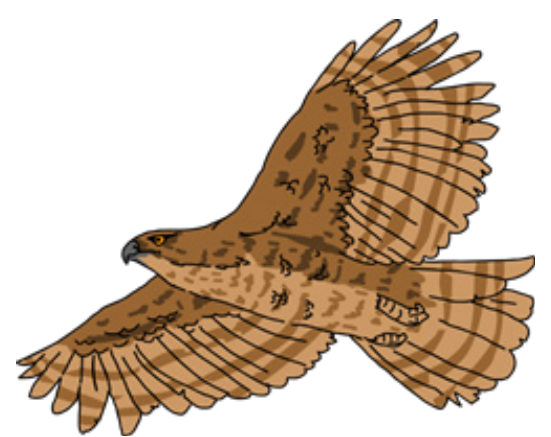

Gambar 10. Elang Jawa (Sumber: Kresnawan, 2018)

4. Motif Tema Potensi Pemandangan Alam

Tasikmalaya memiliki satu ikon lagi yang tidak bisa dilupakan yaitu Gunung Galunggung. Gunung yang mega ini sejak zaman dahulu telah sering menjadi inspirasi penciptaan seni. Gunung Galunggung telah sering menghiasi produk anyaman dengan cara dilukis tangan secara manual.

Penggunaan tema alam Gunung Galunggung akan meneruskan tradisi motif yang telah ada dan melestarikannya.

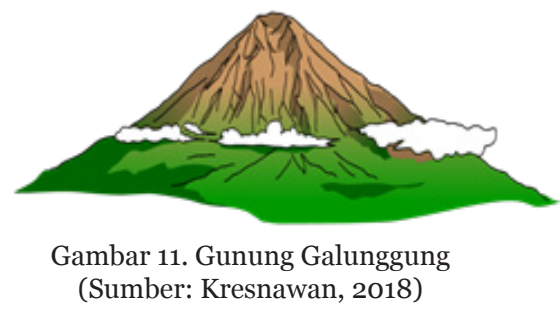

Perancangan Motif Khas Tasikmalaya pada Decoupage untuk Produk dari

Anyaman Pandan

Bentuk kombinasi adalah bentuk motif yang didapatkan dari penggabungan beberapa macam motif yang telah dibuat. Bentuk campuran ini mampu menghasilkan motif yang lebih beragam dan menarik. Di bawah ini adalah beberapa contoh potensial bentuk motif yang berasal dari penggabungan beberapa motif:
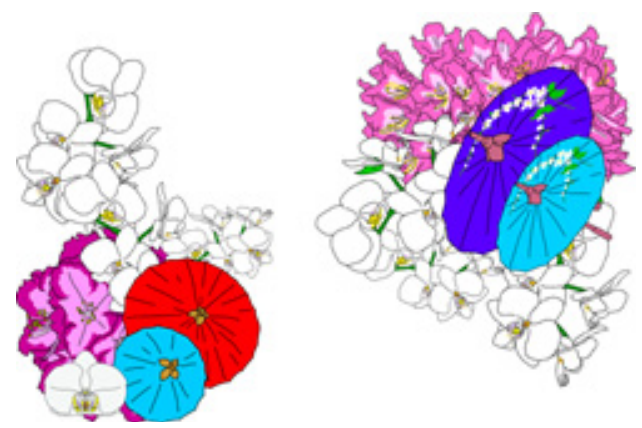

Gambar 12. Kombinasi payung dan bunga (Sumber: Kresnawan, 2018)

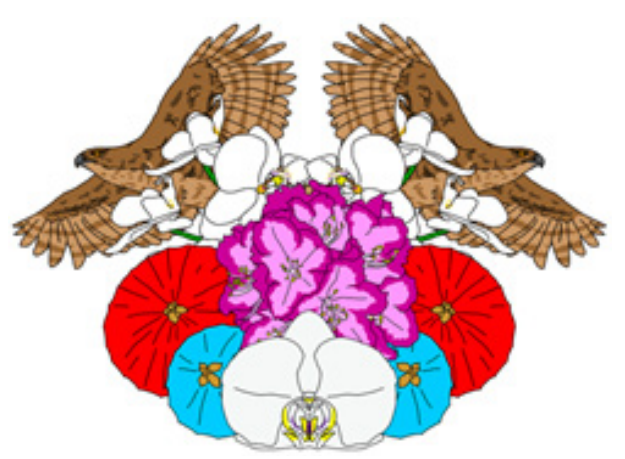

Gambar 13. Kombinasi payung, bunga dan Elang Jawa

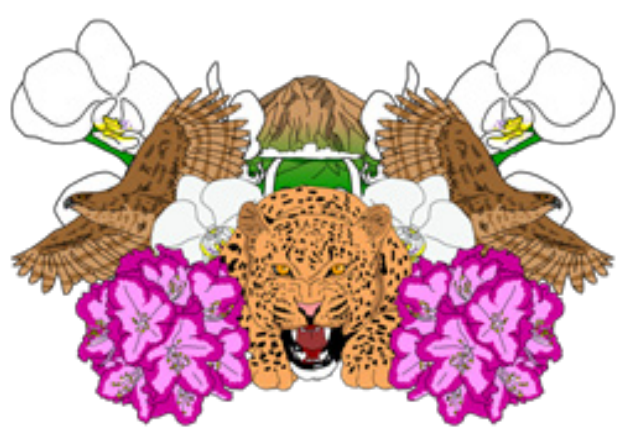

Gambar 14. Kombinasi payung, Bunga, Macan Tutul, Elang Jawa, dan Gunung Galunggung

(Sumber: Kresnawan, 2018) 
Komposisi dan peletakan obyek gambar yang berupa motif khas Tasikmalaya akan menggunakan The Rule of Thirds yaitu aturan yang biasa digunakan untuk teknik fotografi supaya mampu menghasilkan gambar yang menarik.

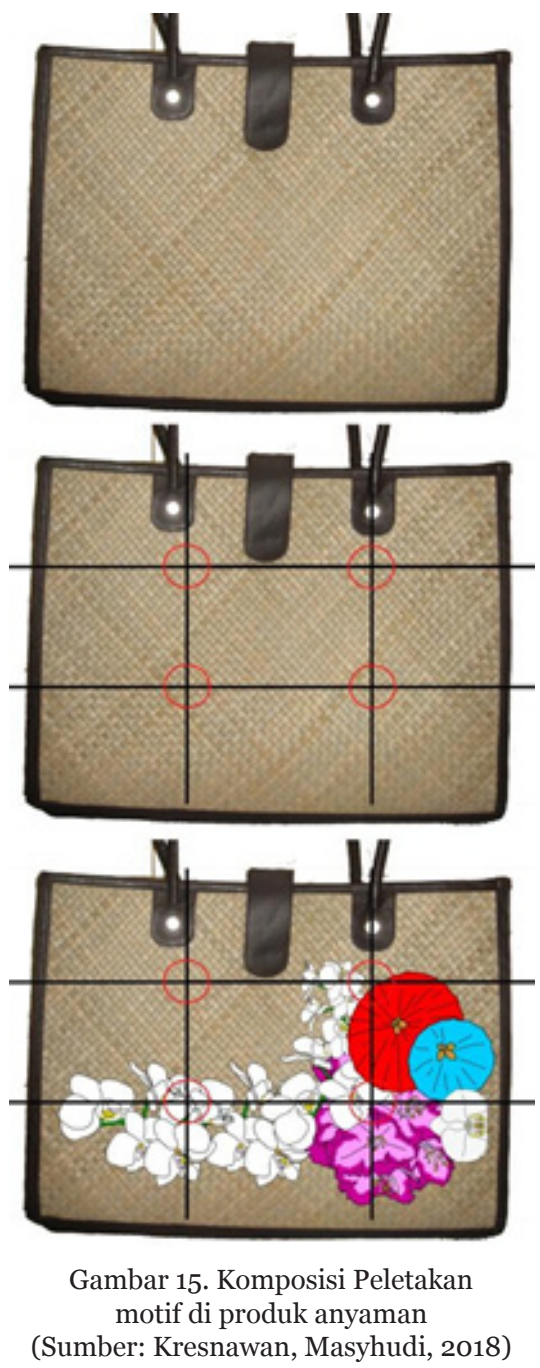

Berikut adalah beberapa contoh pengaplikasian motif decoupage khas Tasikmalaya pada tas anyaman. Peletakannya menggunakan prinsip The Rules of Thirds dengan perpaduan warna yang menarik dari penggabungan beberapa obyek yang yang telah dipilih supaya menjadi lebih indah dan menarik.
Pola pertama adalah asymmetrical balance yaitu objek gambar cenderung berat di salah satu sisi, bisa di sebelah kiri atau di sebelah kanan bidang.

Pola yang kedua adalah symmetrical balance yaitu gambar seimbang atau tepat berada di tengah bidang.

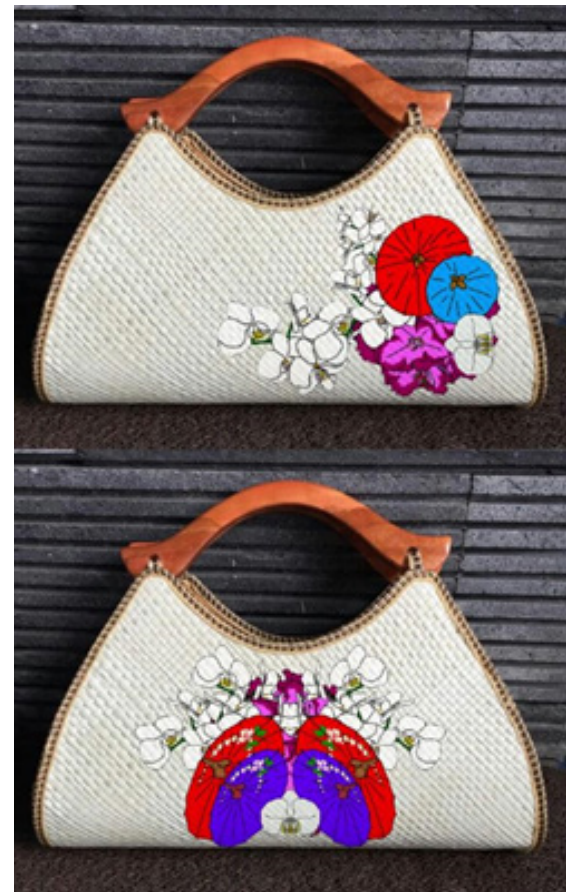

Gambar 16. Produk tas anyaman dengan motif khas tasikmalaya, asymmetrical dan symmetrical balance (Sumber: Kresnawan, Masyhudi, 2018)

Pola penerapan lainnya adalah diagonal balance, obyek ada di bagian atas kanan dan bagian kiri bawah membentuk garis diagonal imajiner.

Pola penempatan objek gambar secara horizontal, terlihat lebih minimalis dengan gambar yang tidak terlalu dominan. Cukup sederhana tapi tetap indah dilihat.

Selain beberapa pola penempatan obyek gambar di atas masih banyak pola lain yang bisa digunakan menggunakan The Rules of Thirds ini. 


\section{Imamul Masyhudi ${ }^{1}$ Kresnawan Budiargo ${ }^{2}$}

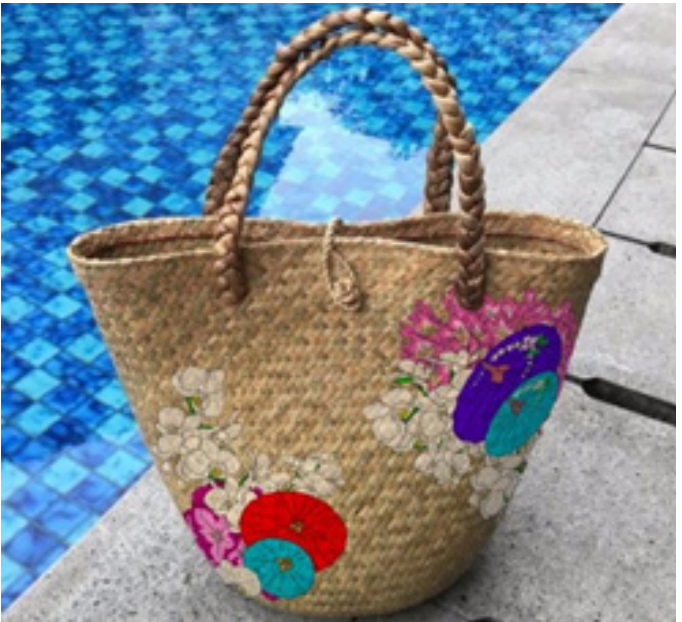

Gambar 17. Produk tas anyaman dengan motif khas Tasikmalaya, diagonal balance (Sumber: Kresnawan, Masyhudi, 2018)

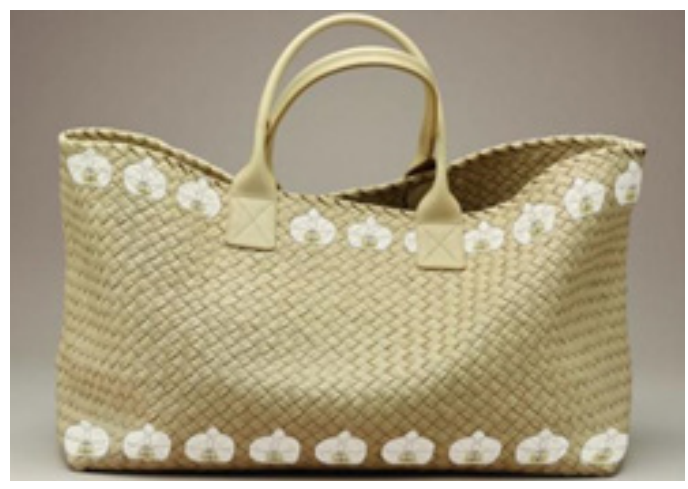

Gambar 18. Produk tas anyaman dengan motif khas Tasikmalaya, pola horizontal

(Sumber: Kresnawan, Masyhudi, 2018)

\section{Kesimpulan}

Produk anyaman dari Tasikmalaya yang telah menembus pasar dunia tentu tidak perlu lagi disangsikan kualitasnya. Sayang dalam penggunaan motif decoupage pada produk khususnya tas belum memiliki ciri khas Tasikmalaya, Hal ini dikarenakan memang tidak ada produk motif decoupage yang beredar di pasaran dibuat berdasarkan ciri khas Tasikmalaya,

Ketiadaan motif khas Tasik- malaya pada motif decoupage untuk produk
Perancangan Motif Khas Tasikmalaya pada Decoupage untuk Produk dari

Anyaman Pandan

anyaman ini menjadi dasar dilakukannya perancangan ini. Dengan menggunakan inspirasi dari potensi yang ada di Tasikmalaya bahkan Jawa Barat, baik itu yang berupa benda, flora, fauna, maupun pemandangan alam, dibuatlah beragam motif yang unik dan bercirikan Tasikmalaya, seperti motif payung, motif Bunga Anggrek Bulan, Bunga Rhododendron, Macan Tutul, Elang Jawa, hingga Gunung Galunggung. Beragam motif ini diterapkan dengan gaya gambar vector yang modern, dinamis, dan kreatif sesuai dengan identitas Kota Tasikmalaya.

Diharapkan dengan adanya motif yang khas dan unik ini, selain memperkaya khazanah visual juga menjadi kebanggaan Kota Tasikmalaya. Selain itu diharapkan juga mampu meningkatkan penjualan para pengrajin anyaman sehingga pada akhirnya akan meningkatkan kesejahteraan mereka. Dengan semakin banyaknya motif maka semakin beragam pula pilihan konsumen. Motif ini juga berpotensi untuk pasar ekspor, di mana gaya naturalis dan minimalis sangat digemari.

Perancangan ini tentu belumlah sempurna, ada beberapa aspek lain yang masih perlu digali lebih dalam, misalnya potensi lain yang mungkin masih bisa menjadi motif decoupage yang khas dan unik untuk hiasan pada anyaman Tasikmalaya.

Di luar kendala yang masih ada semoga perancangan ini benar-benar bisa dimanfaatkan sebagai motif baru yang bisa menjadikan identitas Tasikmalaya lebih terlihat pada produk-produk anyamannya, serta menjadi kekayaan baru non-benda dari Sang Mutiara Priangan Timur ini.

\section{Referensi}

Amanda, G. (22 November 2016) Ini Dia Sejarah Panjang Seni Decoupage. 
https://www.republika.co.id/berita/ohoxxq384/ini-dia-sejarah-panjang-seni-decoupage

Anna, L. K. (13 Desember 2017) 5 Warna Fashion yang Akan Jadi Tren di 2018. https://lifestyle.kompas.com/ $\mathrm{read} / 2017 / 12 / 13 / 110000420 / 5^{-}$ warna-fashion-yang-akan-jadi-trendi-2018

Appadurai, A. 2010. Disjuncture and Difference in the Global Cultural Economy. Theory, Culture \& Society, Vol 7. 295-310 http://www.arjunappadurai. org/articles/Appadurai_Disjuncture _ and_Difference_in_the_Global_Cultural_Economy.pdf

B1 (27 Oktober 2015) Anyaman Tasikmalaya Makin Diminati Pasar Jepang dan Malaysia. https://www.beritasatu. com/ekonomi/317604/anyaman-tasikmalaya-makin-diminati-pasar-jepang-dan-malaysia

Fadilla, R. (31 Januari 2014) Ini Awal Mula Kedatangan Orang Tionghoa ke Nusantara. https://www.merdeka.com/peristiwa/ini-awal-mula-kedatangan-orang-tionghoa-ke-nusantara.html

Fitri, S. (4 maret 2016) Tas Unik Decoupage, Hobi Penghasil Rezeki https://www.republika.co.id/berita/ekonomi/makro/16/o3/o4/ o3i6pw382-tas-unik-decoupage-hobi-penghasil-rezeki.

Gustami, S.P. 2007. Butir-Butir Mutiara Estetika Timur: Ide Dasar Penciptaan Karya Seni Kriya Indonesia. Yogyakarta: Prasista.

Knapp, D. E. 2000. The Brand Mindset. Yogyakarta: Andi

Kotler, \& Armstrong. 2003. Manajemen Pemasaran, Edisi Kesembilan. Jakarta: Gramedia.

Ncan, H. S. (25 Oktober 2017) Sejarah Ta- sikmalaya. https://kumparan.com/ hendra-s-ncan/sejarah-tasikmalaya-1508945668183

Syafril, A. (20 Oktober 2017). Pusat Konservasi Elang Kamojang lestarikan populasi elang jawa https://www. antaranews.com/berita/659725/pusat-konservasi-elang-kamojang-lestarikan-populasi-elang-jawa

Syaifudin, T. M. G. (25 April 2017) Ahli: Habitat Macan Tutul di Jabar Berada di Gunung https://www.tribunnews.com/regional/2017/04/25/ ahli-habitat-macan-tutul-di-jabar-berada-di-gunung

Sugiyono. 2005. Memahami penelitian kualitatif. Bandung: Alfabeta

Tamam, B. MH (25 September 2017) Diskripsi dan Klasifikasi Anggrek Bulan Jawa https://generasibiologi.com/2017/o9/anggrek-bulan-jawa-Phalaenopsis-javanica.html

Rowse, D. 2006. Rule of Thirds. https:// digital-photography-school.com

Wicaksono, M. D. (21 September 2016) Percayakah Anda Kerajinan Ini Berasal dari Tisu? https://finance.detik. com/solusiukm/d-3303468/percayakah-anda-kerajinan-ini-berasal-dari-tisu

Zeegen, L. 2005. The Fundamentals of Illustration. Singapore.:Ava Publishing 